\title{
KARAKTERISTIK PEMIMPIN DALAM ISLAM
}

\author{
Yovenska L.man \\ Institut Agama Islam Negeri Bengkulu \\ Jalan Raden Fatah Pagar Dewa Kota Bengkulu \\ Email: Yovenskasky@gmail.com
}

\section{Olan Darmadi}

Institut Agama Islam Negeri Bengkulu

Jalan Raden Fatah Pagar Dewa Kota Bengkulu

Email: Olan_Darmadi@gmail.com

\begin{abstract}
Abstact: There are many differences of opinion from political elites, statesmen and even ulemas in Indonesia about the worthiness of a leader and the character of the candidates for the leader themselves which are ideal for this ideological Pancasila country. This pluralistic country with many tribes, cultures and even religions has invited controversies that are quite long and sustainable even often arguing with each other even blaspheming with each other with a variety of hujjah which is brought up as a reference in order to defend the arguments of each group both by the elite politics, culture and even religious leaders. Therefore, the author feels it is important to discuss briefly, clearly but densely contained in this journal, how Islam as the majority religion in the equatorial emerald land responds to endless differences of opinion and can result in divisions between the nation's children and even Muslims themselves.
\end{abstract}

Keywords: Difference of Opinion; Feasibility; Islam.

Abstrak: Sebagaimana yang kita ketahui dewasa ini banyaknya terjadi perbedaan pendapat dari para elit politik, negarawan bahkan para ulama di negeri Indonesia tentang kelayakkan seorang pemimpin serta karakter personil calon pemimpin itu sendiri yang ideal bagi negeri yang berideologikan pancasila ini. Negeri yang majemuk dengan banyaknya suku, budaya bahkan agama ini telah mengundang kontroversi yang cukup panjang dan berkelanjutan bahkan tak jarang saling adu argumen bahkan saling hujat satu sama lain dengan beracam hujjah yang di lontarkan sebagai referensi demi mempertahankan argumen masing-masing kelompok baik itu oleh elit politik, budayawan bahkan para tokoh agama. Oleh karena itu penulis merasa penting untuk membahas secara singkat jelas namun padat berisi dalam jurnal ini bagaimankah Islam sebagai agama mayoritas dinegeri jamrud khatulistiwa menyikapi perbedaan pendapat yang tak berujung serta dapat berakibat pada perpecahan antar anak bangsa bahkan umat Islam itu sendiri.

Kata Kunci: Perbedaan Pendapat, Kelayakan, Islam 
AL-IMARAH: Jurnal Pemerintahan dan Politik Islam

Vol. 4, No. 2, 2019

\section{Pendahuluan}

Islam sebagai agama yang lurus dan suci serta diyakini kebenarannya baik secara 'aqli maupun berdasarkan nash Alqur'an maupun Alhadits sebagaimana dikatakan didalam Alqur'an Alkarim

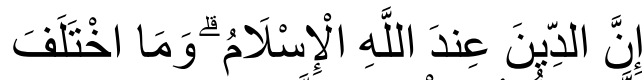

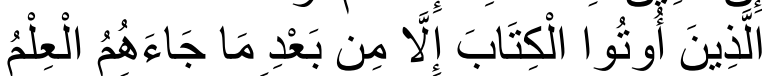

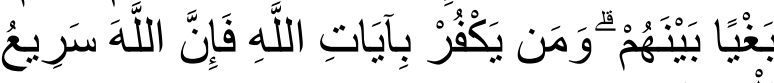

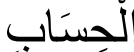

Yang artinya "Sesungguhnya agama yang benr di sisi Allah ialah Islam. Tidaklah berselisih orang-orang yang telah diberi AlKitab, kecuali setelah mereka memperoleh ilmu, karena kedengkian di antara mereka. Barangsiapa yang ingkar terhadap ayat-ayat Allah, maka sesungguhnya Allah sangat cepat perhitungan-Nya.” [Ali 'Imran: 19]

Ayat diatas tlah membuktikan Islam adalah agama satu-satunya yang paling benar dan dengan datangnya Islam telah menghpus syari'at-syari'at sebelumnya yng telah dibawa oleh par nabi terdahulu.Bahkan dalam ayat lain yang berbunyi :

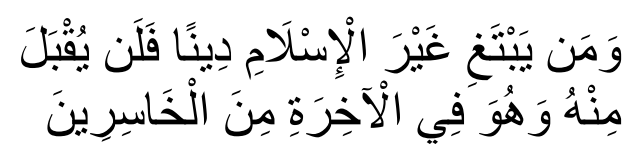

Yang artinya, "Dan barangsiapa mencari agama selain agama Islam, dia tidak akan diterima, dan di akhirat dia termasuk orangorang yang rugi." [Ali 'Imran: 85$]^{2}$.

Ayat diats jelas mempertegas akan kebenaran Islam bahkan secara terang-terangan menyatakan suatu kesalahan yang nyata bilamana ada seoan dari manusiapun yang

\footnotetext{
${ }^{1}$ Alqur'an dan terjemahannya

${ }^{2}$ Ibid

${ }^{3}$ Jalaluddin Assuyuthi. Tafsir jalalain .Darul Fikr Beirut. 2007. h. 27

mencari kebenarn diluar Islam bahkan mereka disebutkan dalam ayat diatas sebagai orangorag yang merugi.Alimam Suyuthi menafsirkan ayat diatas dalam kitabnya yang berjudul tafsir Aljalalain bahwa orang-orang yang memilih agama selin agama Islam mereka tidak akan diterima dikhirat kelak nahkan tergolong orang-orang yang merugi, karena tempat tinggal mereka ialah neraka yang mana mereka akan menempatinya selama-lamanya ${ }^{3}$.

Prof. Quraish Syihab pun didalm tafsirnya menyebutkan dan menerangkan penafsiran tentang ayat diatas bahwasanya mereka yang menghendaki agama dan syariat selain Islam setelah diutsnya Nabi Muhammad SAW tidak akan diperkenankan Allah SWT.pada hari pembalasan nani dalam pandangan Allah dia termasuk orang yang yang menyengsarakan diri sendiri, mereka berhak medaptkan siksa yang pedih ${ }^{4}$

Dalam hadits-hadits nabawipun banyak menerangkan kebenaran Islam yang tak mungkin terbantahkan keabsahannya sebagai satu-satunya agama yang benar sebagaimana sebuah hadits yang dirawatkan oleh sahabat abu hurairah Radhiallahu 'anhu dari Rasulullah SAW beliau bersabda yang artinya, 'Demi Dzat Muhammad yang da dalam genggamannya tidaklah seorang manusia dari umat ini yang mendengar kenabianku, baik yang beragama Yahudi maupun nasrani lantas

\footnotetext{
${ }^{4}$ Quraish Syihab, tafsir almisbah, Tim Lentera Hati, Indonesia 2011.h. 33
} 
dia meninggal tidak dalm keadn beriman dengan ajrn yang aku baa melainkan dia pasti termasuk salah seorang penghuni neraka.' ${ }^{5}$ Hakikakt beriman bukanlah hanya menerima dan meyakini apa-apa yan dibaw oleh Nabi Muhammad SAW saja namun juga harus disertai dengan sikap patuh dan mengikuti semua yang beliau perintahkan serta menjauhi semua hal yang larang.

Islam sebagai agama yang datangnya langsung dari Allah SWT tuhan yang maha esa hadir diteng-tengah kehidupan manusia yang tidak hanya bersifat individual namun juga social yang mencakup kemasyarakatan skala kecil bahkan skala besar berbangsa dan bernegara.Oleh karena itu kita sebagi umat Islam harus senantiasa mengikuti dan mematuhi setiap aturan yang hadir bersamanya melalui perantara nabi Muhammad SAW sebagai bentuk keimanan dan ketaatan sebagai mu'min yang sejati yang senatiasa berpegag teguh pada ajaran agamanya yaitu Islam.Oleh sebab itu, sudah seyogyanya bagi seorang muslim untuk selalu menjadikan ajaran agamanya sebagai pedoman baginya dalam menjalankan kehidupan sehari-hari begitupula kehidupannya dalam berbangsa dan bernegara karena Islam tidak hanya mengatur kehidupan umatnya hanya sebatas dalam hal peribadatan saja namun juga dalam perihal ekonomi, social, budaya serta ketatanegaraan dan politik atau yang lebih dikenal dalam Islam sebagai siyasah.
Kehidupan berbangsa dan bernegara merupakan sebuah keharusan dalam keberlangsungan hidup umat manusia.Sebagaimana firman Allah SWT dalam surat alhujurat ayat 13 yang berbunyi :

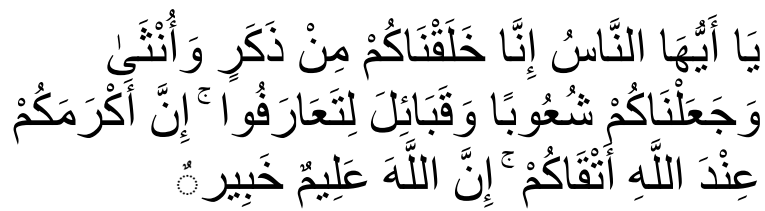
Yang artinya,", Hai manusia, sesungguhnya Kami menciptakan kamu dari seorang laki-laki dan seorang perempuan dan menjadikan kamu berbangsa-bangsa dan bersuku-suku supaya kamu saling mengenal satu sama lain. Sesungguhnya orang yang paling mulia diantara kamu disisi Allah ialah orang yang paling bertakwa diantara kamu.

Sesungguhnya Allah Maha Mengetahui lagi Maha Mengetaui." Allah SWT menciptakan manusia laki-laki dan perempan yang kemudian berank pinak melalui perantara keduanya kemudian menyebarkeerbagai penjuru dunia menjadi berkabilah-kabilah, bersuku serta berbangsa untuk saling mengenal. Tolong menolong serta melengkapi satu sama lain.Itulah hikmahnya daripada umat manusia diciptkan berbangsa-bangsa.

Negara adalah suatu organisasi atau lembaga tertinggi dari kelompok masyarakat yang terdiri dari sekumpulan orang di wilayah tertentu, memiliki cita-cita untuk hidup bersama, serta memiliki sistem pemerintahan yang berdaulat. Sedangkan menurun John Locke definisi negara adalah suatu badan atau organisasi yang dihasilkan dari perjanjian

\section{Pembahasan}

\footnotetext{
${ }^{5}$ Muslim, Shahih muslim, darul fikr.Beirut 2004
}

${ }^{6}$ Alqur'an dan Terjemahannya 
AL-IMARAH: Jurnal Pemerintahan dan Politik Islam Vol. 4, No. 2, 2019

masyarakat. ${ }^{7}$ Berkenaan dengan definisi tersebut tentulah tidak kan tercipta cita-cita mulia umat manusia dalam berbangsa dan bernegara tanpa adanya sebuah control organisasi yang tersusun secara rapi dan sistematis yan mana sistem yang terstruktur tentulah akan memiliki pimpinan teratas dalam yang dapat mengontrol serta menentukan dalam keberlangsungan system itu sendiri.Karena kebenaryang tak terstruktur rapi akan dikalahkan dengan kejahatan yang terstruktur.

Manusia sebagai makhluk Tuhan yang paling sempuntuk menjadi pemimpin dunia yang diciptakan dengan akalnya sebagai alat berpikir tentulah yang paling layak untuk memimpin dunia agar terciptanya sebuah kemaslahatan satu sama lain baik itu sesame manusia maupun manusia dengan alam serta makhluk hidup lainnya.Hal ini telah ditegaskan Allah SWT dalam firmannya yang berbunyi :

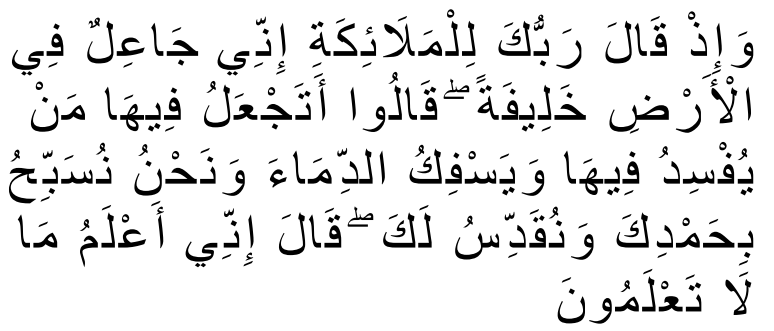

Ingatlah ketika Tuhanmu berfirman kepada para Malaikat: "Sesungguhnya Aku hendak menjadikan seorang khalifah di muka bumi". Mereka berkata: "Mengapa Engkau hendak menjadikan (khalifah) di bumi itu orang yang akan membuat kerusakan padanya dan menumpahkan darah, padahal kami senantiasa bertasbih dengan memuji Engkau dan mensucikan Engkau?" Tuhan berfirman:
"Sesungguhnya Aku mengetahui apa yang tidak kamu ketahui"8.

Ayat diatas menerangkan bahwa manusialah yang paling layak untuk menjadi pemimpin dimuka dunia karena memang tujuan awal penciptaannya adalah untuk menjadi khalifah dimuka bumi.Namun seiring berjalanya waktu, menjadi pemimpin yang merupakan sebuah tugas mulia telah berhasil membangkitkan syahwat manusia untuk berlomba-lomba memperebutkannya dengan berbagai dalil yang notabene hanyalah sebagai pemuas nafsu duniawinya saja tanpa memperhatikan tujuan awal dari kepemimpinan itu sendiri.Sehingga tak ayal banyaknya terjadi upaya saling sikut menyikut bahkan sabotase antar manusia demi menjadikan dirinya penguasa yang memiliki wewenang serta kepopularitasan jika menjabat sebagai pemimpin disebuah wilayah maupun negara Kepemimpinan yang tadinya suatu hal yang mulia serta beban yang berat bagi mereka yang mengembannya kini menjadi suatu kesuksesan dan kenikmatan semu bagi mereka yang berhasil mendapatkannya sehingga mereka lupa bahwa setiap apa yang mereka lakukan dalam kepemimpinannya kelak akan dimintai pertanggungjawaban disisi Allah SWT sebagaimana yang dikatakan Rasulullah Muhammad SAW dalam haditsnya

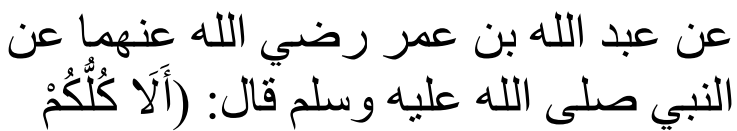

${ }^{8}$ Alqur'an dan Terjemahannya 


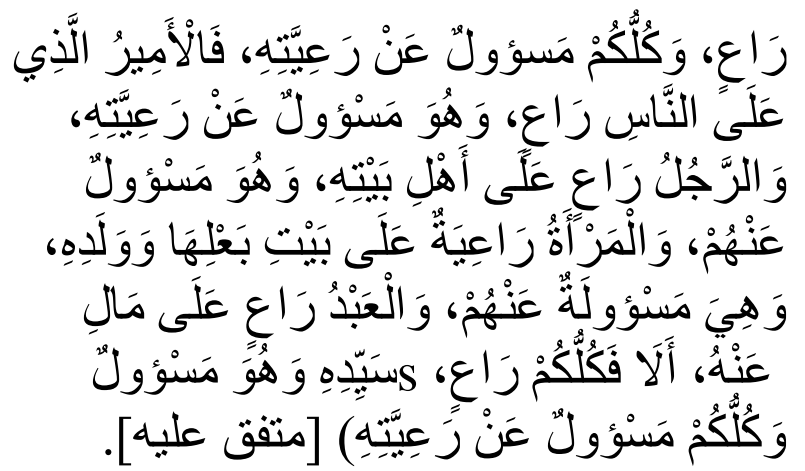

Artinya : Ketahuilah, setiap kalian adalah pemimpin dan stiap pemimpin akan dimintai pertanggung jawaban atas aapa yang dia pimpin.Maka pemimpin yang memimpin manusia dia bertanggung jawab atas rakyatnya.Dan orang yang memimpin atas keluarganya, maka dia bertanggung jawab atas mereka (keluarganya), dan wanita pemimpin (pengawas) dalam rumah suami dan anakanaknya dan dia bertanggung jawab atas mereka.dan hamba sahaya pemimpin (pengawas) pada harta tuannya dan dia bertanggung jawab atasnya.Ketahuilah, setiap dari kalian adalah pemimpin, dan setiap pemimpin akan dimintai pertanggungjawaban atas apa yang dipimpinnya (Muttafaqun 'alaih) ${ }^{9}$.

Hadits diatas merupak sebuah ramburambu bagi setiap orang atas apa-apa yang diperbuatnya terhadap hal-hal yang dia memiliki kuasa serta tanggung jawab dalam memimpin, mengatur, bahkan menguasai.ini menunjukkan bahwa setiap dari kita memiliki wewenang mengemban tugas amanah yang Allah bbebankan kepada kita namun juga agar kita tak lupa bahwa setiap apa yang telah diamanahkan oleh Allah SWT tentunya akan mendapat ganjaran yang setimpal sebagaimana disebutkan Rasulullah SAW dalam haditsnya yang berbunyi :

\footnotetext{
${ }^{9}$ Imam Bukhari. Sahih Bukhari. darul Fikr.Beirut
} 2007.h. 37

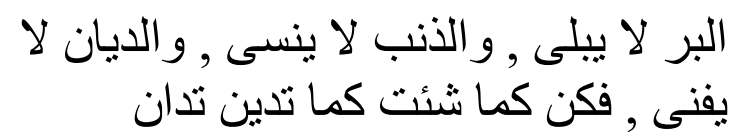

Kebaikkan tidak akan hancur, sedangkan dosa tidak akan dilupakan, dan Dzat yang maha Membalas tidakkan pernah sirna.Maka lakukanlah apa yang kamu mau (lakukan) karena sesungguhnya sebagaimana kamu berbuat seperti itulah kamu akan dibalas ${ }^{10}$.

Banyaknya dalil baik Alqur'an maupun Alhadits yang menghimbau manusia untuk berbuat adil dan amanat menunjukkan betapa pentingnya manusia untuk berbuat baik terhadap sesama dan berpegangan teguh kepada syariat yang telah dibawa oleh Rasulullah SAW serta mengingatkan manusia akan ramburambu penting agar mereka tidak tergelincir dalam jurang kesesatan yang nyata di hadapan mereka karena syariat juga berfungsi sebagai takaran bagi umat manusia dalam perkataan maupun perbuatannya agar tidak berbuat sesuatu yang melanggar dari apa yang telah dinashkan oleh Alqur'an maupun Alhadits yang keduanya merupakan pedoman hidup manusia dalam mengarungi samudera kehidupan didunia yang fana ini.Islam sebagai agama yang sempurna, tentu tidak hanya mengatur umatnya dalam hal peribadatan saja namun juga meliputi berbagai aspek kehidupan sebagaimana fungsi syariat yang ada didalamnya tujuan-tujuan daripada pensyariatan suatu hukum atau yang lebih dikenal dengan maqashidus syari'ah yaitu tujuan Allah SWT dan RasulNya dalam merumuskan hukum Islam.Adapun menurut

${ }^{10}$ Imam Assya'rani . Tanbih Almughtarrin. Darul kutub Al'ilmiyah. Beirut, 2003.h. 15 
AL-IMARAH: Jurnal Pemerintahan dan Politik Islam Vol. 4, No. 2, 2019

Assyaikh Wahbah Az Zuhaili, Maqasid Al Syariah berarti nilai-nilai dan sasaran syara' yang tersirat dalam segenap atau bagian terbesar dari hukum-hukumnya. Nilai-nilai dan sasaran-sasaran itu dipandang sebagai tujuan dan rahasia syariah, yang ditetapkan oleh alSyari' (Allah) dalam setiap ketentuan hukum. ${ }^{11}$ Sementara Menurut Imam Assyathibi tujuan akhir hukum tersebut adalah satu, yaitu mashlahah atau kebaikan dan kesejahteraan umat manusia ${ }^{12}$.

Kemashlahatan yang menjadi tujuan dari syariat ini dibatasi dalam lima hal yaitu : agama, jiwa/nafs, akal, keturunan dan harta. Setiap hal yang mengandung penjagaaan atas lima hal ini disebut maslahah dan setiap hal yang membuat hilangnya lima hal ini disebut denagn mafsadah. ${ }^{13}$ hal ini membuktikan bahwa Islam tidak hanya megatur kehidupan secar personil pribadi masing-masng bahkan juga mengatur kehidupan masyarakat secar universal dalam cakupan yang sangat luas baik masalah keperdatn maupun masalah kepidanaan serta hukumnya bersifat mengikat bagi setiap umatnya tanpa terkecuali.Berikut akan kami jabarkan secara ringkas kelima poin yang trcakup dalam maqasid syariah dalam Islam:

1.Syariat Islam Menjaga Agama

\footnotetext{
${ }^{11}$ Wahbah Zuhaili. Ushul Fiqh Islamy. Damaskus Dar al Fikr, 1986.h. 87

${ }^{12}$ Muhammad Khalid Mas'ud. Filsafat Hukum Islam dan Perubahan Sosial terjemahan oleh Yudian W. Asmin, Surabaya: Al Ikhlas, 1995.h. 22 155
}

Ini adalah poin pertama dan paling urgentnya dalam pensyariatan hukum Islam karena berkaitan langsung dengan keimanan yang mana keimanan seseorang merupakan sebuah tolak ukur dan pembeda antara seorang muslim dengan non muslim.Islam melarang keras umatnya untuk keluar atau murtad dari agama Islam serta meninggalkannya sehingga islam mensyariatkan hukum mati bagi umatnya yang meninggalkan agamanya jika dia tidak mau lagi kembali memeluk islam setelah mendapat peringatan keras dari seorang qadhi yang mengatur jalannya hukum ditengahtengah peradilan islam.

2. Syariat islam menjaga jiwa/nafs

Fungsi tujuan syariat islam berikutnya adalah menjaga jiwa/nyawa bagi setiap hambanya oleh karena itu Islam sangat engecam keras pembunuhan dengan tanpa alas an yang diperbolehkan untuk menghilangkan nyawa seseorang sebagaimana hadits nabi yang diriwyatkan oleh sahabat ibnu mas'ud yang berbunyi :

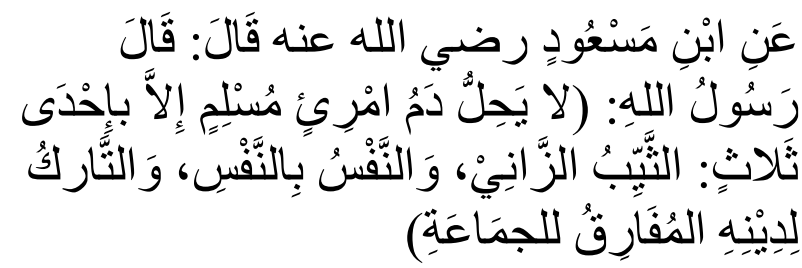

Yang artinya : tidak halal darah seorang muslim kecuali melalui tiga jalan : Seorang yang sudah menikah kemudian berzina, orang

\footnotetext{
${ }^{13}$ Taufik Abdullah (ketua editor). Ensiklopedia Tematis Dunia Islam. Jakarta, PT Ichtiar Baru Van Hoeve.h.13
} 
yang membunuh, dan orang yang meninggalkan agama Islam (murtad) ${ }^{14}$.

Penjelasan hadits diatas ebagaiman yang kami perinci berikut ini :

a. Zina ba'da ihshonin, yaitu jika seorang muslim yang sudah pernah menikah secara syari kemudian berzina maka dengan sebab itu halal darahnya, dengan cara dirajam.

b. Qishosh, yaitu jika seorang muslim membunuh muslim yang lain dengan sengaja maka dengan sebab itu halal darahnya dengan cara di-qishosh.

c. Meninggalkan Agama, yaitu ada 2 pengertian:

1. murtad, artinya keluar dari agamanya dengan sebab melakukan kekafiran.

2. Meninggalkan jamaah, artinya meninggalkan jamaah yang telah bersatu di atas agama yang benar, dengan demikian ia telah meninggalkan agama yang benar. Termasuk makna meninggalkan jamaah adalah jika memberontak imam yang sah.

Hal ini membuktikan bahwa syarat Islam sangat melindungi nyawa setiap penganutnya sebagimana salah satu maqasid syariahnya bertujuan untuk menjaga jiwa/nafs.

\section{Syariat Islam menjaga akal}

\footnotetext{
${ }^{14}$ Imam An nawawi. arba'in Annawawiyah. Darus Salam.Mesir.2005.h.35
}

Manusia yang merupakan makhluk sempurna karena diciptakan bersamaan dengannya akal pikiran ntuk membedaan mana yang enar dan mana yang salaah, mana yang baik dari yang buruk hal inilah yang membedakan manusia dengan hewan sebagaimana dikatan oleh imam abu zaid Abdurrahman alakhdhari dalam kitabnya yang berjudul sullamul manuraq الانسان حيوان الناطق (manusia adalah hewan yang berakal) ${ }^{15}$.

4. Syariat Islam menjaga keturunan.

Dalam syariat Islam tidak ada ajaran bagi pemeluknya untuk tidak menikah sebagimana ada pada ajaran agama lain yang bahkan menganggap memilih hidup untuk tidk menikah merupakan sebuah keistimewaan atau dikenal dengan hidup selibat atau tidak menikah sebagaimana yang terjadi pada ajaran khatolik Roma.Pada awalnya mereka tidak menganut ajaran yang demikian, penjalahan hidup selibat baru mulai masuk ke dalam gereja-gereja umat kristiani yang belakangan menjadi gereja Katolik Roma. Menurut buku Celibacy and Religious Traditions, ini merupakan sebuah gerakkan yang sejalan dengan gerakan baru yang muncul di kekaisaran Romawi untuk mengendalikan keinginan seksual dari para penganutnya.

\footnotetext{
15 Abu Zaid Abdurrahman alakhdhari. Sullamul Manuraq.Alhidayah.Surabaya.2002.h. 48
} 
Lalu pada abad-abad yang berikutnya, dewan gereja dan Bapak-Bapak Gereja menganjurkan kehidupan selibat bagi para pemimpin agama (pastor). Mereka menganggap hubungan seksual itus sebuah perbuatan yang mencemarkan dan sangat tidak cocok dengan tugas seorang pemimpin agama. Walaupun demikian, menurut Encyclopædia Britannica, "hingga abad ke-10, banyak pastor dan bahkan beberapa uskup yang memiliki istri”.

Pada Konsili Lateran yang saat itu diadakan di Roma pada tahun 1123 dan 1139, para imam diwajibkan untuk tidak menikah. Dan sampai sekarang, itu menjadi sebuah ketetapan resmi Gereja Katolik Roma. Dengan begitu, gereja tidak akan kehilangan kekuasaan dan pendapatannya, karena jika seorang imam menikah, dia akan mewariskan properti gereja kepada anak keturunannya.Hal ini digunakan untuk menjaga keberadaan aset-aset yang dimiliki oleh gereja-gereja mereka.

Hal seperti ini tentulah tidak berlaku didalam islam, karena islam sangat memanusiakan manusia yang mana manusia diciptakan dengan memiliki hasrta dan nafsu untuk makan minum bahkan berhubungan seks.Namun Islam mengatur kehidupan manuisa agar tidak salah dalam menempatkan sesuatu yang pada hakikatnya merupakan fitrahnya agar tetap berada pada jalan yang

\footnotetext{
${ }^{16}$ Alqur'an dan Terjemahannya

${ }^{17}$ Ibid
}

lurus sehingga tidak terjebak dalam jurang kedurjanaan dan semena-mena menggunakan nafsu mereka yang pada akhirnya akan mengakibatkan terjerumusnya seorang anak manusia kedalam jurang kenistaa.lalu Islam hadir dengan mensyariatkan sebuah pernikahan yang boleh bahkan dianjurkan bagi setiap pemeluknya.Sebagaimana dapat kita saksikan banyak nya dalil baik Alqur'an maupun Alhadits yang berbicara tentang hal tersebut seperti firman-firman Allah SWT berikut ini :

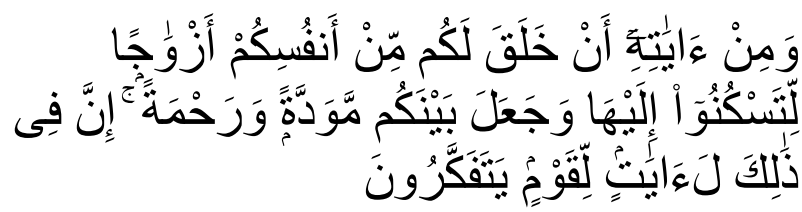

Yag artinya: Dan diantara daripada tandatanda kekuasaannya ialah Dia (Allah) menciptakan untuk kalian isteri-isteri dari jenis kalian sendiri, supaya kalian cenderung dan merasa tenteram kepadanya, dan dijadikanNya diantara kalian rasa kasih dan sayang. Sesungguhnya pada yang demikian itu benarbenar terdapat tanda-tanda bagi kaum yang berpikir.

QS. Ar. Ruum (30):21 ${ }^{16}$

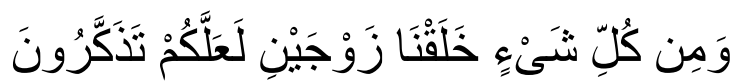

Yang artinya : Dan segala sesuatu telah kami jadikan berpasang-pasangan, supaya kalian mengingat kebesaran Allah [QS. Adz Dzariyaat (51):49] ${ }^{17}$.

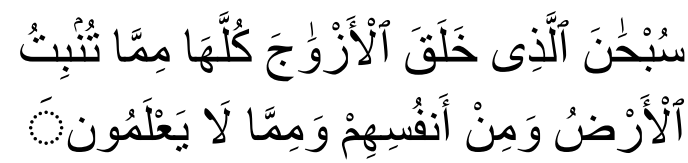

Yang artinya : Maha Suci Allah yang telah menciptakan berpasangan-pasangan semua nya, baik dari apa yang ditumbuhkan (muncul) oleh bumi dan dari diri mereka maupun dari apa yang tidak mereka ketahui. [QS. Yaa Siin (36):36]. ${ }^{18}$

${ }^{18}$ Ibid 


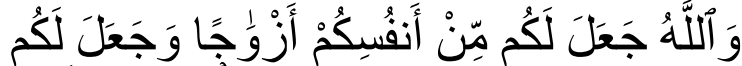

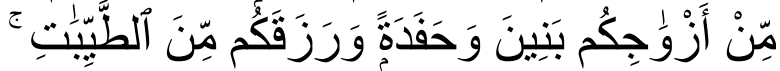

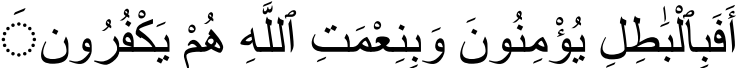

Yang artinya : Bagi kalian Allah telah menciptakan pasangan-pasangan (istri-istri) dari jenis kalian sendiri (manusia), kemudian dari istri-istri kalian itu Dia ciptakan bagi kalian anak cucu keturunan, dan kepada kalian Dia berikan rezeki yang baik-baik. QS. An Nahl (16):72 ${ }^{19}$.

Ini adalah sebagian dari ayat-ayat Alqur'an yang menjadi bukti bahwa Islam mengajarkan kepada umatnya sebuah pernikahan melalui pensyariatan hukumnya.Karena seyogyanyalah bai umat manusia untuk saling menikah satu sama lain karena fitrahnya pada dasarnya ialah kecenderungan untuk berpasang-pasangan sebagaimana yang telah dijelaskan pada ayatayat diatas.Dalam Alhadits pun demikian, banyaknya anjuran tentang pernikahan sebagaimana yang terdapat pada hadits-hadits berikut ini :

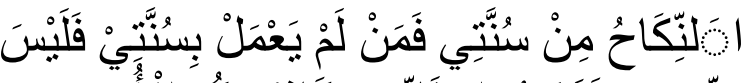

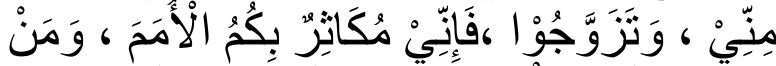

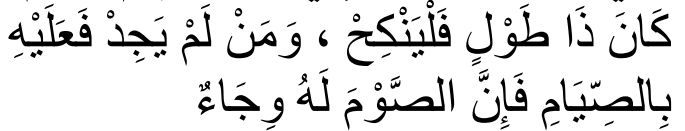

Yang artinya: "Menikah adalah sunnahku, maka barang siapa yang tidak melaksanakan sunnahku, dia bukan termasuk dari golonganku. Menikahlah kalian, Karena sesungguhnya Aku berbangga dengan banyaknya jumlah kalian (nanti) di hadapan seluruh umat.. Dan barang siapayang telah memiliki kemampuan (untuk menikah), maka menikahlah ! Dan barang siapa yang belum

\footnotetext{
${ }^{19}$ Ibid

${ }^{20}$ Imam Bukhari. Sahih Bukhari.Darul Fikr. Beirut 2003.h. 15
}

mampu, hendaklah dia berpuasa, karena puasa itu adalah merupakan perisai baginya (dari berbagai syahwat dan nafsu $)^{20}$.

Hadits yang diriwayatkan dari sahabat Anas bin Malik, Rasulullah SAW bersabda :

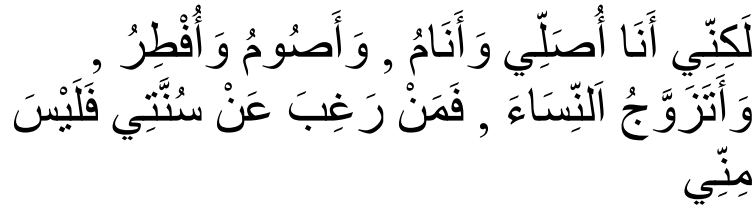

Yang artinya: Akan tetapi Aku sholat, dan tidur, berpuasa, dan berbuka,serta mengawini perempuan. Maka baran gsiapa yang membenci sunnahku, dia tidaklah termasuk dar umatku. (Muttafaqun 'Alaih) ${ }^{21}$

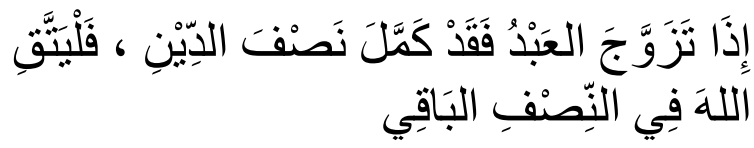

Yang artinya: Jika seseorang menikah, maka sungguh $d$ ia telah menyempurnakan separuh dari agamanya. Karenanya, bertakwalah kepada Allah pada separuh yang lainnya. (HR. Al-Baihaqi)

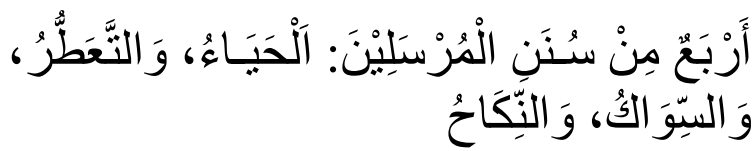

Yang artinya: "Empat perkara yang termasuk sunnah para rasul, yaitu sifat malu, memakai wewangian, bersiwak dan menikah". (HR. Tirmidzi dan Ahmad) ${ }^{22}$

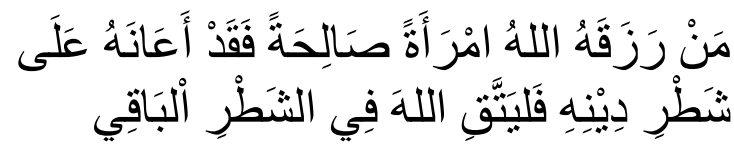

Yang artinya: "Barangsiapa yang Allah telah berikan rezeki kepadanya berupa istri shalihah, berarti Allah telah menolongnya atas separuh agamanya. Maka bertakwalah kepada Allah untuk separuh yang lainnya“. (HR. AtThabrani)

${ }^{21}$ Imam Muslim, Sahih Muslim .Darul Fikr. Beirut 2007.h. 18

${ }^{22}$ Imam Attarmidzi. Sunan Attarmidzi. Darul Kutub Al islamiyah.Beirut 2004 
Riwayat lain dari sahabat Abdullah bin Mas'ud berkata, Rasulullah SAW bersabda:

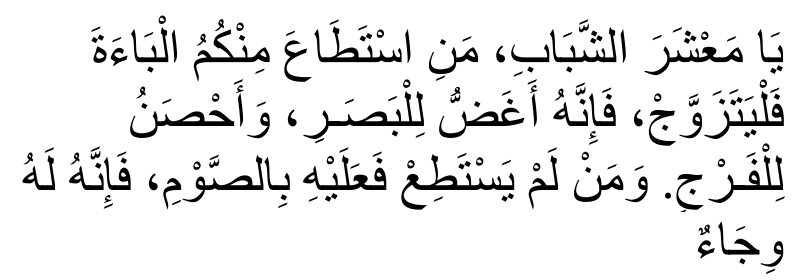

Yang artinya: "Wahai para pemuda, barang siapa diantara kalian yang telah mampu untuk berkeluarga, hendaknya dia segera menikah. Karena hal tersebut dapat menundukkan pandangan serta menjaga kemaluannya. Dan barangiapa yang belum memiliki kemampuan, hendaknya dia berpuasa, karena dengan berpuasa dapat mengendalikanmu“. (Muttafaqun 'Alaih) ${ }^{23}$.

Masih banyak lagi hadits-hadits yang menerangkan tenang pensyariatan pernikahan bahkan keutamaan keutamaannya. Hal ini menunjukkan saking pentingnya pernikahan didalam Islam bahkan bagi orang-orang yang menjalakannya akan mendapat berbagai ganjaran berupa pahala serta keutaman.Semua itu tentu selaras dengan hikmah daripada penciptaan manusia secara berpasang-pasangan untuk melengkapi satu sama lain melalui jalur perkawninan yang nantinya dari perkawinan itu akan menurunkan anak cucu dari manusia itu sendiri sehingga terciptalah keberlangsungan kehidupan umat manusia diatas muka bumi ini.bahkan rasulullah SAW menganjurkan umatnya untuk menikah serta memotivasi agar mereka memperbanyak reproduksi sehingga terlahirlah banya anak keturunan dari umatnya yang kelak akan beliau banggakan di akhirat kelak.

5.syariat Isam menjaga harta.

Selain mengatur masalah perihal peribatan yang bersifat vertical. Syariat islam juga berperan penting dalam mengatur hubungan manusia satu dengan yang lainnya atau yang lebih dikenal dengan mu'amalah.karena Islam pada dasarnya bukan hanya menetapkan etika tata cara berhubngan antara seorang hamba dengan Tuhannya atu yang lebih dikenal dengan hablu minallah namun juga mengatur hubungan antar manusia satu dengan manusia lainnya atau hablu mina annas.Isla mengatur antara hak dan kewajiban yang harus terpenuhi dan terjaga antara umat manusia, sehingga dalam hukumnya Islam sangat mengecam suatu perbuatan yang merugikan orang lain atau bahkan merampas harta kepemilikkan dengan cara yang tidak dibenarkan dalam Islam.Hal ini tentu saja berfungsi demi menjaga hak seseorang atas apa yang telah dimilikinya berupa harta agar tidak direnggut orang lain dengan car mencuri, ghasab atau bahkan merampok.oleh Karena itu Islam sangat tegas terhadap mereka yang merampas kekayaan yang dimiliki oleh orang lain bahkan hukuman pidana bagi para pelaku penurian.hal ini tertuang dalam ayat Alquranyang berbunyi

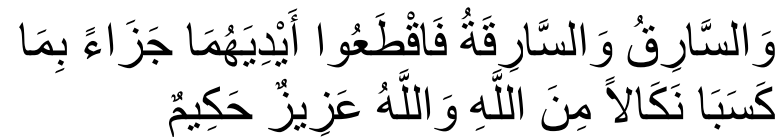

\footnotetext{
${ }^{23}$ Imam Bukhari.Sahih Bukhari.Darul Fikr.Beirut.2003.h. 25 
Yang artinya : lelaki yang mencuri dan perempuan yang mencuri, potonglah tangan keduanya (sebagai) pembalasan bagi apa yang mereka telah kerjakan dan sebagai siksaan dari Allah. Dan Allah Maha Perkasa lagi Maha Bijaksana. (Qs. Al-Maidah : 38) ${ }^{24}$.

Karena Islam merupakan agama yang bersifat universal, yang senantiasa mengatur setiap umatnya baik dalam urusan-urusan mereka secara individual maupun secara bermasyarakat dan bernegara maka tentulah dalam kehidupan sehari-hari Islam memberikan aturan yang harus dipatuhi oleh setiap pemeluknya juga rambu-rambu yang tak boleh dilalui oleh setiap daripada umatnya agar tercipta kehidupan yang aman tentram dan damai serta terciptanya sebah ketaatan dan kesadaran akan pentingnya hukum Islam supaya menjadi perantara kebahagiaan bagi setiap umatnya baik didunia maupun diakhirat yang tentunya setiap hukum yang ditetapkan oleh syariat sangat memperhatikan dari pada kemaslahatan-kemaslahatan untuk umat itu sendiri serta menjauhkan mereka daripada kemafsadatan-kemafsadatan yang dapat menjerusmuskan mereka dalam jurang kehancuran serta kehinaan jika rambu-rambu yang berupa laranga-larangan itu mereka langgar.

\section{Hubungan Antara Agama Dan Negara}

Islam sebagai agama yang universal tentunya tidak hanya mengatur umatnya hanya dalam sesuatu yang berhubungan dengan peribadatan saja namun segala sesuatu yang berhubungan dengan berbagai macam aspek kehidupan yang berkaitan dengan diri manusia secara pribadi, social. Budaya, adat istiadat serta kehidupan berbangsa dan bernegara.Hal ini semakin menunjukkan bahwa Islam sebagai agama yang benar dan diyakini kebenarannya berperan penting dalam berbagai aspek kehidupan umatnya dalam mencapai maslahat dan menghindarkan umatnya dari kemudharatan yang dapat membahayakannya baik selama kehidupannya didunia maupun diakhirat nanti sebagaimana telah dijelaskan sebelumnya tentang maqashid syari'ah.Begitupun halnya dalam kehidupan bernegara, Islam tetunya berperan penting dengan aturan norma-normanya yang mengikat setiap umatnya agar tidak keluar dari apa yang menjadi aturan dalam islam yang juga tentunya untuk kebaikkan umat Islam itu sendiri.Maka Islam tak akan pernah lepas dari kehidupan bernegara dan tetap menuntut untuk diterapkannya pola-pola kenegaraan secara Islami sebagaimana yang dikatakan oleh seorang raja Persia yang bernama sasan yazdagird kepada puteranya (226-240 M) yang berbunyi :

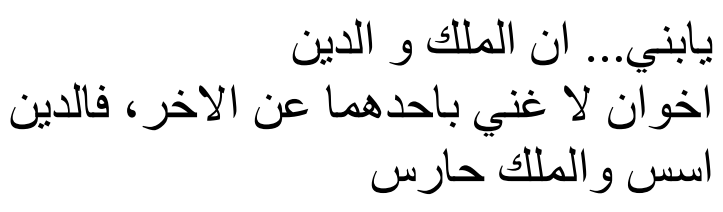

Wahai Anakku...Negara Dan Agama Bagai Dua Saudara Yang Tak Terpisahkan. Agama Adalah Fondasi Sedangkan Negara Adalah 
Penjaganya ${ }^{25}$. (Kitab As sulthan, Ibnu Qutaibah Ad- Dainuri Wafat Th.364 H).

Dari sini jelaslah bahwa sanya Agama dan Negara saling berkaitan sama lain, bahkan beliau mengatakan keduanya bagaikan dua saudara yang saling elengkapi satu sama lain yang tak mungkin terpisahkan yang satu dari yang lainnya.Agama sebagai asas sementara Negara sebagi penjaganya agar terciptanya kehidupan berbangsa dan bernegara sebagaimana yang menjadi harapan setiap manusia.

\section{Pentingnya Pemimpin Dalam Islam}

Kepemimpinan dalam Islam dinamakan $\mathrm{Al}$ imamah yang berpungsi sebagai pelaksana tugas kenabian yang sudah tidak ada dengan wafatnya nabi Muhammad SAW sebagai penjaga agama dan pemimpin dunia demi terciptanya kemaslahatan untuk setiap manusia dan hukumnya wajib secara ijma' para ulama ${ }^{26}$.

Pentingnya kepemimpinan dalam islam, saking pentingnya banyak sekali hadits Nabi yang menyebutkan keutamaan bagi seorang pemimpin yang adil dan amanat terhadap rakyatnya.Bahkan sebagian ulama mengatakan sebuah Negara yang memiliki seorang pemimpin bodoh sekalipun lebih baik daripada tidak adanya seorang pemimpin di negara tersebut, walaupun dipimpin oleh seorang yang

\footnotetext{
${ }^{25}$ Ibnu Qutaibah Ad- Dainuri, As sulthan, Wafat Th.364 H
}

bodoh seperti sama saja dengan tidak adanya pemimpin karena keberadaannya seperti tidak ada.

Karena saking pentngnya keberadaan pemimpin ditengah kehidupan manusia, Islam sangat mengatur hal-hal yang berkaitan dengan seorang calon pemimpin dan bagaimanakan karakter pemimpin menurut islam yang ideal.Berikut penulis akan paparkan secara ringkas apa saja yang mnjadi karakter bagi para calon pemimpin dalam pandanhan islam.

\section{Karakter Pemimpin Dalam Islam}

Didalam literature-literatur karya ulama terdahulu sebenarnya telah banyak disebutkan karakter bagi para calon pemimpin yang ideal yang dapat diharapkan keamanatannya serta membawa keadilan bagi seluruh rakyatnya.Sebagaimana yang disebutkan oleh Imam Al mawardi dalam kitabnya yang berjudul $\mathrm{Al}$ ahkam As sulthaniyah syarat bagi seorang pemimpin dalam Islam sebagai berikut

\section{Adil beserta dengan syarat-syaratnya ${ }^{27}$.}

2.Ilmu, keilmuan yang berkaitan dengan kepemimpinan secara syari'at tentunya

3.Sehat panca indera seperti Pendengaran, penglihatan dan lisan

\footnotetext{
${ }^{26}$ Al mawardi. Al ahkam As sulthaniyah .darul kutub al ilmiyah. Beirut 2013.h.28

${ }^{27}$ Abu ya'la. al ahkam As suthaniyah . darul fikr Beirut 2007.h. 29
} 
4.Sehat secara fisik / anggota tubuhnya

5.Memiliki pandangan (Visi) dan

kebijaksanaan untuk kemaslahatan rakyat

6.Keberanian untuk melindungi wilayah kenegaraan dan melindungi rakyatnya serta berjihad memerangi musuh.

7.Nasab (Hendaknya dari golongan orang Qurays jika memungkinkan) ${ }^{28}$.

Itulah tujuh hal syarat yang harus dimiliki oleh seorang pemimpin dalam islam menurut para ulama ahli dalam hukum siyasah syar'iyah sebagai landasan bagi setiap muslim yang akan menjadi pemimpin agar menjdi pemimpin yang adil, amanat, sehingga dapat membawa kemaslahatan bagi rakyat yang dipimpinnya sehingga dia mendapat kebaikkan didunia maupun akhirat sebagai seorang Imam adil seperti yang disebtkan dalam hadits Nabi SAW yang mana seorang imam yang adil tidak ada balasan baginya yang layak kecuali surga dan kelak akan diberi naungan oleh Allah SWT pada saat hati tidak ada naungan kecuali naungan keridhaan Allah SWT Tuhan semesta alam.

\section{Pustaka Acuan}

Abu ya'la. al ahkam As sulthaniyah. darul fikr. Beirut 2007

Abu Zaid Abdurrahman alakhdhari. Sullamul Manuraq. Alhidayah.Surabaya
Al mawardi. Al ahkam As sulthaniyah. darul kutub al ilmiyah. Beirut 2013

Alqur'an dan terjemahannya

Ibnu Qutaibah Ad- Dainuri. As sulthan. Wafat Th.364 H

Imam An nawawi. arba'in Annawawiyah. Darus Salam, Mesir

Imam Assya'rani. Tanbih Almughtarrin. Darul kutub Al'ilmiyah. Beirut, 2003

Imam Attarmidzi. Sunan Attarmidzi. Darul Kutub Al islamiyah.Beirut 2004

Imam Bukhari. Sahih Bukhari. darul Fikr.Beirut. 2007

Imam Bukhari. Sahih Bukhari.Darul Fikr.

Beirut 2003

Jalaluddin Assuyuthi. Tafsir jalalain. Darul Fikr Beirut. 2007

John Locke. Two Treatises of Civil Government. London 1689

Muhammad Khalid Mas'ud. Filsafat Hukum Islam dan Perubahan Sosial. terjemahan oleh Yudian W. Asmin. Surabaya: Al Ikhlas. 1995

Muslim. Shahih muslim. darul fikr.Beirut 2004 Quraish Syihab. tafsir almisbah. Tim Lentera Hati, Indonesia 2011

Taufik Abdullah (ketua editor). Ensiklopedia Tematis Dunia Islam. Jakarta. PT Ichtiar Baru Van Hoeve

Wahbah Zuhaili, Ushul Fiqh Islamy. Damaskus: Dar al Fikr. 1986

\footnotetext{
${ }^{28}$ Al mawardi, Al ahkam As sulthaniyah .darul kutub al ilmiyah. Beirut 2013.h. 99
} 